\title{
Opinion
}

\section{The Dirty Business of Dying: From Charitable Endeavor to Cut-Throat Enterprise, Hospice in America is a Shameful Shadow of its Former Self}

\author{
Carrie Alani, MA, RN, CHPPN* \\ Director, Patient and Family Experience atV Care Hospice Services of Illinois, Northbrook, IL 60062, USA \\ ${ }^{*}$ Corresponding author \\ Carrie Alani, MA, RN, CHPPN \\ Director, Patient and Family Experience atV Care Hospice Services of Illinois, Northbrook, IL 60062, USA; E-mail: alanipublishing@gmail.com
}

\section{Article information}

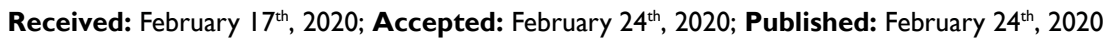

\section{Cite this article}

Alani C. The dirty business of dying: From charitable endeavor to cut-throat enterprise, hospice in America is a shameful shadow of its former self. Palliat Med Hosp Care Open J. 2020; 6(I): 5-6. doi: 10.17।40/PMHCOJ-6-134

I 'm learning there comes a time in life - providing you are both willing and able - where you review where you've come. You take stock of where you've been. Have you made the world a better place or just endured existence from the cheap seats? As a nurse who has committed a life's work to easing the suffering of others, I applaud breakthroughs that have become best practices: the World Health Organization (WHO) ladder of pain control; use of the pain assessment in advanced dementia (PAINAD) in non-verbal dementia patients; advanced certification in hospice and palliative care (even in pediatrics); a myriad of ways to deliver comforting concoctions and so much more. However, the deepest and richest treasure in the clinician's toolbox remains the Medicare Hospice Benefit.

Had you been terminally ill before the mid-1980s, you might have received care in your home from well-intentioned volunteers or nurses who were paid for their services through philanthropic means (the hospice they worked for paid them through donations it received from others). But that changed in 1983 with the designation of the Federal Medicare Hospice Benefit. "The Benefit' now provided Medicare beneficiaries with courage for high-quality end-of-life care by accredited agencies.

The idea of hospice wasn't new.

The United States borrowed the recipe for hospice from Europe, where the care began in the mid-1800s with terminally ill being cared for compassionately in homes by well-intentioned volunteers. The cornerstone of hospice is use of an interdisciplinary team, where each member addresses an aspect of care (social worker, chaplain, medical director, etc). is paramount. Like most things ripped off from our European ancestors, we in America feel the need to improve it. Over time, the field of hospice - and its cousin, palliative care - have become a well-researched, evidencebased field worthy of its own subspecialty. Considered the model for quality care for people facing a life-limiting illness, hospices seeking to be reimbursed for services were mandated to use this patient-centered, interdisciplinary team to deliver care. Best of all, hospice agencies could now bill Medicare a daily per diem rate for each appropriate patient. In exchange, hospices were now required to provide care, medications, equipment and oxygen to care for patients. The plan was to save millions of dollars by keeping patients home, out of the high-ticket hospital and costs could be contained. Finally, well-meaning agencies whose true passion was to care for those at life's end, could be reimbursed fairly, timely and predictably. Good hospices used the influx of funds to expand services, raise wages for care staff and strengthen programs, even adding adjuvant services, such as massage therapy, aromatherapy and other comfort-enhancing endeavors. Ambitious agencies expanded unfunded programs, such as pediatric palliative care and charity care. Family and staff satisfaction surveys of hospice care were largely positive and life - for those who cared for the dying - was oddly good. So good, it caught the eye of big business who smelled irresistible, fresh blood in a revenue stream.

Over time, those downwind of hospice (home health companies, nursing homes and hospital systems themselves) caught a whiff of something juicy and profitable. With reimbursement changing and regulations tightening, what better way to stack the deck but with the dying? Even non-healthcare companies jumped into the fray (think RotoRooter/Chemed owning a hospice). Agencies, both non-profit and private, began to pop up like creeping vines in a jungle. Forward-thinking agencies invested in hospice homes - stand-alone facilities where folks could stay if their symptoms were extreme or the family lost its collective marbles while caring for dying father or mother. Ironically, the re- 
imbursement rate for patients in a hospice home was nearly seven times that of the daily per diem rate. The problem? The facilities, tastefully decorated and aromatherapy-infused, cost to run whether full or empty. If every patient was adequately managed at home, why bring them to the hospice home? Savvy leaders culled over their census and looked for obvious targets. While most were likely appropriate, the allure of the reimbursement was just too tempting and crafty CEOs found ways to keep their inpatient hospice homes full.

\section{Alas, American greed has led us to the demise of true hospice care}

I am unsure as to what and where the tipping point was. Some blame the same general economic downturn that caused General Motors to cut 75,000 jobs in the mid-90s; others point to military action in the Gulf. What I am sure of is that the tectonic plates on which hospice rested shifted and contorted. And in the newlycreated spaces, leaders who had no business caring for the terminal ill, suddenly found a crack, blossomed and began blocking out the sun of proper agencies. The big hospices could out-market, outadvertise and out-incentivize well-intentioned, smaller providers. Perhaps the change was initially positive. Having trained eyes on expenditures, write-offs and revenue helped many agencies capture lost monies. But, slowly, it was the bottom line driving care, not patient needs. Colleagues of mine of both non-profit and private agencies felt it like an earthquake. Nurse to patient ratios crept higher and higher; contracts for durable medical equipment were negotiated aggressively and things like oxygen and bedside commodes hung in the balance like the market price of lobster. Cheap is king. Why buy the best gauze dressings for a wound when a patient is only going to live for a week? Why provide this medication or that supplement if it's not needed and spikes your pharmacy spend? Suddenly, coming on to hospice care meant something different: a nurse who used to care for 12 patients is now carrying a load twice that. There goes the intangible value of good nursing care. Call centers are set up to handle the waterfall of after-hours requests for help and assistance. Patients ripe for inpatient use are shuttled to hospice homes for symptoms or family burnout - some warranted, some exaggerated to keep the beds full and reimbursement high. Families gripe about low-quality products, hit-and-run visits from haggard staffs and the results show: the soaring satisfaction surveys of a decade ago nosedive. According to a 2019 Department of Health and Human Services (HHS) Office of Inspector General (OIG) investigation this past July, hundreds of hospices across the US received 'failing grades.' Nearly $80 \%$ of agencies had at least one significant deficiency while most had '...multiple failures.'

While some facilities, their owners and staff faced criminal charges for care deficiencies, it's still all about the money. Federal investigators have their hands full. Just one investigation in North Texas found more than $\$ 60$ million in Medicare fraud. Multiply that by countless other programs still unknown and the bill hits the stratosphere. There goes cost savings. Woefully, the very program designed to save money and care for our nation's most vulnerable openly raped and pillaged. The OIG's answer? More over sight to hospices is needed.

\section{I don't see that working, do you?}

Perhaps the greatest and saddest loss in our American hospice experiment is the realization that capitalism - when applied to the dying - doesn't fit. We've taken an honorable model of care, steeped in European tradition, and killed it and watch big business dance on its grave in a red dress. While it's anyone's guess what end-oflife care will look like in the next decade, it's clear if it's Federally funded, it won't be around for long. If I'm still alive and breathing, look me up. If I'm able, come to my house and I'll take care of you for free.

I've got a big basement. 